\title{
A LITERATURA NO RÁDIO E NA TELEVISÃO: TRADUÇÕES INTERSEMIÓTICAS NA AMÉRICA LATINA?
}

\author{
LITERATURE ON RADIO AND TELEVISION: \\ INTERSEMIOTIC TRANSLATIONS IN LATIN AMERICA?
}

\section{Dennys Silva-Reis*}

\section{RESUMO}

O presente trabalho se propõe a examinar as relações entre literatura e as mídias do rádio e da televisão no âmbito latino-americano. Considerando que a literatura é sempre revisitada pelos meios de comunicação, vê-se este translado como tradução intersemiótica e também como forte difusão da arte literária, especialmente pelos gêneros midiáticos telenovela e radionovela. A fim de comprovar nossa hipótese assinalamos dois produtos das artes-relés: as radionovelas da série Mi novela favorita e a telenovela Los Miserables. Tenta-se mostrar o quanto a ficção é amplamente consumida pelo público latino-americano e que mais da metade do que se considera obras ficcionais pertencem ao conjunto das obras literárias transmutadas. Palavras-chaves: tradução Intersemiótica; literatura; radionovela, telenovela, artes-relés.

\section{ABSTRACT}

This paper aims to examine the relations between literature and the media of radio and television in Latin American context. Considering that literature is always revisited by the mass media, we view this transfer both as intersemiotic translation and a strong diffusion of literary art, especially through the midiatic genres of telenovela and radionovela. To verify this hypothesis, we approach two products from these arts-relais: the radionovelas of the series $\mathrm{Mi}$ novela favorita and the telenovela Los Miserables. We try to show how this kind of fiction is broadly consumed by Latin American public; more than half of these fictional works are literary works the have been transmuted.

Keywords: intersemiotic translation; literature; radionovela; telenovela; arts-relais.

\section{INTRODUÇÃO}

Ao se percorrer a história das relações entre literatura e mídias na América Latina, é possível perceber que existe um forte amálgama entre as obras literárias e os meios de difusão de informações. No século XIX, foram os folhetins os responsáveis

\footnotetext{
* Universidade de Brasília (UnB), Programa de Pós-Graduação em Literatura (POSLIT), Brasília (DF),Brasil.reisdennys@gmail.com
} 
pela propagação e popularização da literatura, visto que as obras literárias só eram transformadas em livros após algum sucesso em formato de folhetim. Já no início do século XX, foi a vez do rádio tomar o lugar do folhetim (MEYER, 1996). O rádio, além do acesso indireto à literatura, também causou furor ao tornar audível a voz dos personagens e suas ambiências emocionais, o que de certa forma trazia o texto literário para perto do cotidiano dos potenciais leitores. E, a partir da década de 1950 - em particular dos anos 1980 em diante -, a televisão, bem difundida entre todas as camadas sociais, se torna mais uma mídia de divulgação da literatura com a transmissão da imagem pronta para o telespectador. No mesmo período surge também a fotonovela com a ampla exploração da imagem. Logo, grosso modo, poderíamos traçar do seguinte modo uma linha literária-midiática: leitura da palavra, escuta da palavra e imagem da palavra - sem levarmos em consideração, no entanto, as discussões do que vêm a ser a palavra e a imagem porque, como se sabe, há interligações entre os conceitos.

Essa retrospectiva só enfatiza o quanto as outras mídias têm sido importantes para a literatura, em sentido estrito, mas nos recorda igualmente que o dito "leitor literário" muitas vezes não recepciona a obra apenas na leitura do texto em formato de livro, mas também por outros meios, como bem nos lembra Itamar Even-Zohar (2013, p. 33-34):

Para começar, o consumo direto de textos integrais foi e segue sendo periférico para a maioria dos consumidores "diretos" de "literatura", sem falar dos "indiretos". Todos os membros de qualquer comunidade são ao menos consumidores "indiretos" de textos literários. Em tal qualidade, nós, como membros da comunidade, simplesmente consumimos uma quantidade de fragmentos literários, digeridos e transmitidos por variados agentes culturais e integrados no discurso diário. Fragmentos de velhas narrações, alusões e frases feitas, parábolas e expressões cunhadas, tudo isto e muito mais constitui o repertório vivo depositado no armazém de nossa cultura.

Quanto aos consumidores "diretos", ou seja, as pessoas voluntária e deliberadamente interessadas nas atividades literárias, não é claro se o grosso das pessoas desse grupo (minoritário) está fundamentalmente preocupado pelo ato de ler ou em participar de várias outras formas no sistema literário. Quantos daqueles que iriam conhecer um célebre escritor ou escritora realmente leram sua obra? Ou quantos o terão lido de tal modo que lhes permita ao menos uma discussão semi-profissional em certo modo sobre a obra? Os consumidores de literatura (como os de música, teatro, balé e muitas outras atividades socioculturais institucionalizadas) consomem frequentemente a função sociocultural dos atos envolvidos na atividade em questão (que às vezes assume abertamente a forma de "acontecimento" ["happening"]), mais do que o que é concebido como "o produto". Realizam esta forma de consumo inclusive quando obviamente consomem "o texto", mas a questão aqui é que podem realizá-la ainda que nenhum consumo de textos esteja envolvido.

Ou seja, a obra literária pode, sim, ser usufruída mediante outros tipos de manifestações literárias para além somente do texto impresso ou digital. E ainda 
podemos dizer mais: o texto literário não precisa estar preso somente ao âmbito verbal para ser lido. Outras linguagens e meios artísticos também podem ser condutos de apreciação da obra literária - obviamente, não em sua totalidade visto que, uma vez consumido por outro meio, tem-se uma interpretação do textos literários dentre tantas outras possíveis. Isto parece ser ainda mais concreto na contemporaneidade ao notarmos que, muitas vezes, se sabe da obra literária e de seu autor apenas por ter assistido um filme ou documentário, ouvido uma entrevista de rádio ou poema musicado, ter ido a um espetáculo de teatro ou visto uma instalação de temática literária, enfim, por ter tido contato com a adaptaçãa ${ }^{1}$ do literário.

Salienta-se que ler a obra literária na íntegra em sua própria mídia - a verbal - tem uma diferença sinestésica quando comparado a ter conhecimento dela por meio de sua adaptação. Entretanto, não se pode negar que as adaptações de obras literárias tangenciam a literariedade, quando buscam se valer de alguns meios de correspondência, compensação, alusão, referência ou não-distanciamento daquilo que é próprio à obra literária em sua mídia verbal e que estão de alguma forma em conexão com o sistema literário. Além disso, cabe notar que cada linguagem artística e midiática tem seus públicos e campos específicos, por vezes bem delimitados. Por exemplo, os jogadores de viodeogames literários ocupam nichos de consumo diferentes dos cinéfilos amantes de adaptações de obras literárias. O apreciador do jogo Les Miserables: Cosette's Fate (2013, by Mastertronic) raramente é o mesmo do filme Les Miserables (2012, Tom Hooper), embora ambos tenham tido acesso à obra de Victor Hugo por meios diferentes e interações singulares próprias às mídias e às artes que mais prezam. Obviamente, esse acesso à obra hugoana é apenas uma das interpretações ou leituras possíveis por outra mídia.

No âmbito da América Latina, nos parece que as duas mídias que têm um alcance extremante eficaz e rápido são o rádio e a televisão². As adaptações de obras literárias produzidas para esses dois meios surtem mais efeitos que quaisquer outras artes entre os latino-americanos. Isso se dá porque essas duas mídias são as mais populares e de mais fácil acesso em todas as camadas sociais dos países latinoamericanos (CANCLINI, 2007; RONCAGLIOLO, 1996; GALAY, 2015, RADIO LIBRES, 2017). Somado a isso, são mídias em que, uma vez comprados seus aparelhos transmissores, os conteúdos difundidos são gratuitos e ficam disponíveis em casa, sem a necessidade de ir a um lugar específico para fruição, como nos

\footnotetext{
1. A palavra adaptação neste trabalho será usada como produto ou resultado final da transposição de uma obra literária para outro(s) gênero(s) - no caso da presente pesquisa, gêneros audiovisuais.

2. As palavras rádio e televisão são utilizadas nesse artigo tanto como suporte físico (mídia = suporte) quanto como sistema de produção, emissão e transmissão de um conteúdo em linguagem própria (radiofonia e televisionamento $=$ mídia $=$ meio de comunicação $)$.
} 
casos do cinema e do teatro, por exemplo, ainda que em menor grau se observa o crescimento vertiginoso de plataformas de streaming e canais de conteúdo com curadoria em que é possível assistir filmes e peças de teatro filmadas sob a condição de que se seja assinante pagante desses meios. Vale a pena mencionar ainda que tanto programas radiofônicos quanto programas televisionados estão cada vez mais disponíveis nas plataformas da internet e de fácil acesso, uma vez tendo a mídia computador em casa.

\section{DAS MÍDIAS ÀS ARTES-RELÉS NA AMÉRICA LATINA}

Os estudos no campo da comunicação vêm demonstrando cada vez mais a crescente expansão das mídias rádio e televisão em todos os países pertencentes à região chamada América Latina (GARZA, 2005; LOPÉZ, 2012). Isso se deu basicamente pelos processos de democratização de grande parte daqueles países, bem como pela descoberta do poder indutivo e formativo dessas mídias nos domínios da educação, da cultura, do comércio, do interesse público e do interesse comunitário (TORRES, 2009).

Para se ter uma ideia, o número de emissoras de rádio é superior a 25.000, sendo que, na América Latina e Caribe, é possível classificá-las da seguinte forma:

\begin{tabular}{|l|c|}
\hline \multicolumn{2}{|c|}{ Quadro 1: Os nomes das rádios na América Latina e Caribe } \\
\hline México & Concessionárias e permissionárias \\
\hline $\begin{array}{l}\text { Colômbia, Honduras, Panamá, Peru, Bolívia, } \\
\text { Brasil, Uruguai, Paraguai }\end{array}$ & Comerciais \\
\hline $\begin{array}{l}\text { Guatemala, Honduras, Colômbia, Venezuela, } \\
\text { Equador }\end{array}$ & Mídias Públicas \\
\hline $\begin{array}{l}\text { Nicarágua, Honduras, Colômbia, Venezuela, } \\
\text { Equador, Peru, Bolívia, Brasil, Uruguai, Paraguai }\end{array}$ & Comunitárias \\
\hline Costa Rica, Bolívia & Culturais \\
\hline Bolívia & Originárias \\
\hline Peru, Brasil, Paraguai & Educativas \\
\hline
\end{tabular}

Fonte: (LÓPEZ, 2012, p. 39)

O número crescente de emissoras de rádio (RADIOS LIBRES, 2017), que apresenta proporção semelhante ao de emissoras de televisão, revela de alguma forma o quanto essas duas mídias estão presentes no cotidiano dos latinoamericanos. Tal fato está imbricado com a tendência da arte na modernidade, que 
envolve basicamente três grandezas da vida do homem moderno: a energia (ou intensidade), a pressa e a dimensão. Segundo Paul Valéry (283-84):

Se não houver, pela manhã, nenhum grande infortúnio no mundo, sentimos um certo vazio: 'Não tem nada, hoje, nos jornais!', dizemos. Eis-nos tomados pelo fato, estamos todos envenenados. Tenho, portanto, razão em dizer que existe para nós uma espécie de intoxicação pela energia, tal como há uma intoxicação pela pressa e uma outra pela dimensão.

As crianças frequentemente acham que um navio nunca é grande o bastante, que um carro ou um avião nunca são rápidos o bastante, e a ideia da superioridade absoluta da grandeza quantitativa, ideia cuja ingenuidade e grosseria são evidentes (espero) é uma das mais características da espécie humana moderna. Se investigarmos em que a mania da pressa (por exemplo) afeta as virtudes do espírito, encontraremos facilmente à nossa volta e em nós mesmos todos os riscos da intoxicação de que eu falava (tradução nossa).

Ou seja, a intoxicação que sofre o homem moderno pelas três grandezas descritas acima por Valéry afeta seus sentidos, mas também a maneira como ele concebe seu ambiente e a forma como se relaciona com os objetos à sua volta. Isso porque, como afirma Pierre Schaeffer (2010, p. 30), teórico da música,

[...] não só nossos sentidos sofrem ataques: o tempo e o espaço já não são senhores de si. $\mathrm{O}$ silêncio esvai-se e a ausência quase: o silêncio, que é esse tempo esvaziado de sons, o rádio o preenche; a ausência, que é a possibilidade de escapar do objeto, a televisão vai supri-la. Os sons e as imagens estão por toda a parte. E esse fenômeno de ocupação do éter coincide, sem jogo de palavras, com este outro fenômeno político, que já não haja em parte alguma do mundo espaço virgem, terra livre: completou-se a ocupação "dos territórios pelas nações organizadas, a supressão dos bens que não têm dono".

É sabido que essa "ocupação" pelas imagens e pelos sons não é nova. Tal fenômeno existe desde que as chamadas belas-artes se estabeleceram no mundo ocidental, seja como movimento, seja como técnica, seja como forma de apreciação. O que há de novo é a popularização das artes, bem como o avanço da arte moderna, que trouxe para as sociedades uma intersecção entre mídias e artes, ou seja, novas técnicas, suportes e meios de expressão antes inimagináveis. Há, em suma, uma transformação de objetos em arte, por meio de novos instrumentos, com a criação de novos públicos, novos gêneros, novos estilos e novas regras de uso e de execução.

Pierre Schaeffer (2010, p. 32) defende a tese de que as artes do século XX têm em sua própria natureza o fato de "serem inseparáveis de um meio mecânico de expressão". O autor considera que cinema, rádio e televisão estão intimamente imbricados por um relé, ou seja, um dispositivo de transmissão. E, talvez por conta disso, sejam concebidas como artes "menores", ou mesmo somente como mídias, especificamente a televisão e o rádio. Entretanto, a fim de diluir essas diferenças entre as artes clássicas (em particular aquelas que dependem da linguagem verbal) e 
as artes-relés, artes que dependem de um meio mecânico de transmissão, Schaeffer faz uma elucidação tão clara que preferimos citar na íntegra ao invés de parafrasear:

[...] desde a aparição da linguagem e seu uso nas artes correspondentes (poesia, teatro, romance, etc.), surge a confusão, não só possível, mas obrigatória e permanente. A linguagem tem duas funções e a primeira é ser um instrumento e não uma arte, um relé e não uma criação. Ela é útil e utilitária antes de gratuita e capaz de beleza. Ela designa antes de sugerir. Ainda que só por essa semelhança fundamental e funcional, o cinema e o rádio deveriam ser comparados à escrita e à linguagem.

Mas levemos adiante o paralelo. Antes do cinema e do rádio, qual é pois o meio à disposição do homem para deixar traço das coisas e das ideias, escapar às falhas da memória, às imprecisões da linguagem oral, às traições do gesto? A escrita. É verdade que ela começa sendo um signo e a reprodução de um gesto. Ela é primeiro concreta exatamente como o cinema. Mas logo adquire poder de abstração: aos caracteres descritivos às letras-imagens sucede o alfabeto, e esses signos mesmos assumem um estilo. Tornando-se importantes enquanto caracteres. A escrita readquire beleza formal. Ela é não só pontuada para comodidade de leitura, mas diagramada para o prazer do olho. E chegamos à arte gráfica moderna, aos caracteres rebuscados. A diagramação torna-se uma arte. Por fim, a diagramação pode ser reproduzida mil vezes e, amplamente distribuída, unir todo um país, percorrer o mundo. É a edição, que está para a escrita como a difusão para o rádio e a distribuição ou a televisão para o filme. Procurem bem. Só mesmo as artes gráficas para prefigurar exatamente o cinema. Quanto ao rádio, o estudo de sua porção característica, à qual chamei dinema, mostrará que ele é também uma escrita sonora com sua pontuação, seus caracteres, sua diagramação (SCHAEFFER, 2010, p. 68).

A partir da afirmativa acima, percebe-se que literatura, rádio e televisão têm em comum o fato de serem linguagens singulares com a capacidade de deformar, transmitir e informar a arte. Partilham da renúncia essencial, ou seja, por mais que produzam arte - entendida como produto estético realizado pelo homem -, esta sempre será uma cópia do original. Logo, a imagem nunca será o objeto, a modulação nunca será o som, a caligrafia nunca será a ideia em si.

Apesar desse tronco comum, cabe ressaltar que as premissas das artes-relés - em especial o rádio, o cinema e a televisão - são a ubiquidade, a simultaneidade e o gigantismo (SCHAEFFER, 2010, p. 58). Todas dizem respeito ao triunfo da arte no espaço, no tempo e na intensidade que se dedica a ela. Tanto cinema e televisão se fazem presentes pela imagem quanto o rádio pelo som. Mesmo que não se preste atenção na imagem luminosa da televisão ligada na sala ou no som do rádio ligado no carro, de alguma forma estes solicitam o olhar, a audição. Tanto televisão/cinema quanto rádio são capazes de restituir eternos presentes, de manter vivos os mortos. Em várias casas e em vários carros, ao mesmo tempo, pessoas diferentes veem e ouvem as mesmas coisas. Além disso, as imagens do cinema/televisão e os sons do rádio estão fora da proporção do hábito que temos de ver e ouvir no cotidiano, o que de certa forma aguça mais os ouvidos e olhos do receptor, pois observa-se e 
ouve-se com maior energia e intensidade aquilo que o som ou a imagem realça a mais - eis o gigantismo das mídias.

A unidade das três dimensões possivelmente faz com que surja um efeito de presença cada vez mais forte nas artes-relés. Talvez seja esse efeito de presença um simulacro de existência - que faça o rádio e a televisão serem tão assíduos no cotidiano dos latino-americanos. Somada a esse efeito de presença, a possibilidade de reproduzir o movimento e de introduzir um ritmo também contribui para que o rádio e a televisão se adaptem aos seus receptores.

Será tanto na adequação de públicos quanto na busca de políticas de sucesso do rádio e da televisão que vão surgir, na América Latina como um todo, vários gêneros radiofônicos e televisivos. Contudo, os gêneros de maior sucesso são os ficcionais, que começaram pela importação, em particular dos Estados Unidos, e depois foram ganhando originalidade, cores e enredos nacionais (GARZA, 2005).

Convém frisar que a importação de gêneros ficcionais radiofônicos e televisivos - em sua maioria traduzidos - foi de suma importância no que tange ao conhecimento das regras e técnicas de feitura de tais produtos, bem como na criação do hábito entre os latino-americanos do consumo dessas obras ficcionais do rádio e da televisão, apesar de, em razão disso, ter havido uma grande estadunidensização midiática inicial de tais produções radiofônicas e televisivas.

\section{A RADIONOVELA E A TELENOVELA}

Dentre os gêneros ficcionais de maior destaque na América Latina, dois sobressaem: a radionovela e a telenovela.

A telenovela - caracterizada como uma narrativa televisiva dividida em vários capítulos com clímax inicial e final, transmitidos todos os dias em canal aberto de televisão (BALOGH, 2002) - é realmente um gênero televisivo que faz e fez muito sucesso nos países latino-americanos. Ao lado deste gênero está seu irmão midiático: a radionovela, que tem as "mesmas" características narrativas do gênero televisivo, mas com trabalho singular feito pelos sons (música, ruídos, voz e silêncio). A radionovela teve seus anos dourados anteriores à década de 1970 (CESÁRIO et alii, 2006).

Tanto a radionovela quanto a telenovela são dois gêneros midiáticos e, por vezes, artísticos em que a literatura também foi revisitada ou serviu de inspiração para produções originais. Poderíamos mencionar, a título exemplificativo, que a primeira telenovela da TV Bandeirantes foi Os Miseráveis (1967) "baseada" na obra de Victor Hugo e transmutada para a televisão por Walter Negrão; e as primeiras 
radionovelas eram adaptações de obras literárias, intituladas "radioteatros" por se fundamentarem em performances radiofônicas de textos de dramaturgia. Cabe registrar que as principais radionovelas de maior sucesso na América Latina eram cubanas, com especial destaque para $\mathrm{O}$ direito de nascer (1948) do escritor, jornalista, crítico teatral e compositor Félix B. Caignet.

Interessa notar que não somente o rádio e a televisão se alimentaram da literatura, mas que o caminho inverso também ocorreu. Podemos exemplificar com dois romances: La tía Julia y el escribidor, publicado em 1977, de autoria de Mario Vargas Llosa, e Through the Arc of the Rain Forest (Matacão, uma lenda tropical, na tradução brasileira) publicado em 1990, de autoria de Karen Tei Yamashita.

No romance de Vargas Llosa, há o personagem Pedro Caramacho que trabalha como escritor, adaptador e radioator de radionovelas. $\mathrm{O}$ romance narra como se fazia a compra dos textos cubanos a fim de serem dramatizados nas emissoras de rádio limenhas. Além disso, um outro personagem, Mario Varguistas, jovem empregado de uma das rádios limenhas, demonstra o anseio das emissoras de rádio por uma produção nacional, visto que ele tinha como sonho ser escritor de radionovelas. Em suma, no romance aparecem tanto a temática da radionovela quanto elementos da escrita deste gênero: descrições minuciosas, clímax do texto radiofônico produzido a partir da vivência do autor de radionovelas, argumentos melodramáticos.

Já em Matacão, uma lenda tropical, Karen Tei Yamashita escreve um romance espelhado no gênero telenovela. A autora nipo-americana que passou quase dez anos no Brasil para estudar a imigração japonesa, tendo contato com a telenovela e compreendendo o alcance que tal gênero tinha entre seus espectadores, se utiliza de uma das características da televisão - a simultaneidade ${ }^{3}$ - para a construção de seu romance em torno de seis personagens (Kazumasa Ishimaru, Batista, Tânia Aparecida, Mané da Costa Pena, Chico Paco e Jonathan B. Tweep) e três lugares diferentes (Brasil, Japão e Estados Unidos). O recurso a núcleos com tramas distintas, que também é outro elemento típico da telenovela, é utilizado na arquitetura do texto de Tei Yamashita, pois no início tais enredos não se tocam, mas no prosseguimento da leitura se vê que há um entrelaçamento entre eles e seus personagens. Apesar desta escritora não ser latino-americana, nota-se que nesta obra literária ela se utiliza de ingredientes próprios da arte comum da região: a telenovela, a tradição literária do realismo fantástico e uma das ambientações narrativas em espaço brasileiro.

3. Apesar de considerar neste artigo a simultaneidade como uma característica muito mais comum, e até mesmo própria, da televisão, não se pode negar que o princípio de simultaneidade já existia na literatura desde o século XIX, em particular, no texto teatral (DUFIEF, 2001). 
Provavelmente, o que mais une essas três artes (literatura, rádio e televisão) é o gênero narrativo melodrama. Há muitos críticos que afirmam que tanto radionovela quanto telenovela são a continuação do melodrama folhetinesco e romanesco, especialmente oriundos do século XIX. Entretanto, não se pode esquecer que o melodrama é originário das artes dramáticas e está intimamente ancorado no momento em que a encenação começa a ser mais importante que o próprio texto, consequentemente dando maior ênfase aos apelos visuais e à ambiência de espetáculo.

O gênero melodramático do teatro está estruturado na tríade sentimentalismo, emoção e impacto sobre a plateia. Sua estrutura gira em torno da oposição de personagens dicotômicos que representam o bem e o mal, o vício e a virtude etc.; da alternância entre momentos de profunda desolação, tristeza e aflição e extremada alegria, euforia e serenidade; e com dois itinerários frequentemente marcados, a saber: a reparação da injustiça e a busca da realização amorosa (HUPPES, 2000). Tal estrutura, que também apareceu no romance-folhetim e na fotonovela, e que continua na radionovela e na telenovela, é de fácil assimilação pelo grande público, e de alguma forma faz que este se torne parte do universo onírico criado, já que este tipo de obra ficcional é construído de certa forma para agradar ao seu receptor.

A preocupação de agradar ao público parece recente, ainda mais com os aspectos mercadológicos das mídias cada vez mais aguçados, mas é possível ver que essa característica melodramática foi muito bem firmada por um dos seus mentores, Victor Hugo, que no prefácio de sua peça teatral Ruy Blas faz a seguinte afirmativa:

Três espécies de espectadores compõem o que se convencionou chamar de público: primeiramente, as mulheres; segundamente, os pensadores; terceiramente, a multidão propriamente dita. O que a multidão pede exclusivamente à obra dramática é ação; o que as mulheres querem nela antes de tudo é paixão; o que nela buscam mais especialmente os pensadores são caracteres [...]. Isso se deve a que a multidão pede ao teatro sobretudo sensações; a mulher, emoções; o pensador, meditações. Todos querem um prazer; mas, estes, o prazer dos olhos; aquelas, o prazer do coração; os últimos, o prazer do espírito. Daí, em nosso palco, três espécies de obras bem distintas: uma vulgar e inferior, as duas outras ilustres e superiores, mas que satisfazem, todas as três, uma necessidade: o melodrama para a multidão; para as mulheres, a tragédia que analisa a paixão; para os pensadores, a comédia que pinta a humanidade [...]. Para qualquer homem que fixe um olhar sério sobre as três espécies de espectadores que acabamos de listar, é evidente que todas as três têm razão. As mulheres têm razão em quererem se emocionar, os pensadores têm razão de quererem ser ensinados, a multidão não está errada em querer se divertir. Dessa evidência se deduz a lei do drama (HUGO, 1997, p. 27-28) (tradução nossa).

Essas afirmações de Hugo, tomadas algumas liberdades e guardados alguns cuidados, parecem bem atuais, especialmente quando se observa que muitas radionovelas e telenovelas sempre tiveram o intuito de chamar a atenção dos mais 
diversos públicos, se adaptando quando necessário às mais diferentes plateias e gostos. E é com esse intuito que a radionovela e a telenovela advindas de obras literárias surgem, a fim de despertar o interesse de públicos que, também gostando da emoção e da ação, são mais fascinados pela reflexão ou, como nota Hugo pelos "caractères". Um bom exemplo disso nos dá o professor de história do rádio e da televisão Flávio Luiz Porto e Silva (2005, p. 52), ao se reportar à telenovela Roque Santeiro (exibida pela Rede Globo em 1984):

Baseada na peça O berço do berói, de Dias Gomes, este, em parceria com Aguinaldo Silva, desenvolveu a história com possibilidades de leitura que dependiam do nível de instrução, percepção e interesse do público. Assim, para "o pensador", a cidadezinha de Asa Branca, onde se passa a trama, surgia como uma metáfora do próprio Brasil, dominado pelos poderes ligados à política, à igreja e à economia. No triângulo amoroso central - Sinhozinho Malta, viúva Porcina e Roque Santeiro -, provável paródia do triângulo amoroso do filme Casablanca, as mulheres encontravam a "paixão", presente também nas várias tramas paralelas. E a multidão, o vasto público, apenas uma história "engraçada", com tantas personagens "divertidas" e mais aquela viúva Porcina a berrar pela empregada "Mina! Minaaa...!", grito imitado por tantos dessa multidão, que "não está errada ao querer ser divertida".

Não se pode negar que existem outras obras ficcionais radiofônicas e televisivas que também demonstram a preocupação de atrair os mais diversos públicos, com seus letramentos plurais; entretanto, parece-nos ser a revisitação do literário nessas obras que faz que algumas tenham mais sucesso que outras.

Numa pesquisa recente, envolvendo apenas oito países latino-americanos (Argentina, Brasil, Chile, Equador, México, Paraguai, Uruguai e Venezuela) o pesquisador Javier Martínez Garza (2005, p. 163) apresenta o seguinte quadro a respeito da oferta de programas na América Latina:

\begin{tabular}{|c|c|}
\hline \multicolumn{2}{|c|}{$\begin{array}{c}\text { Quadro 2: Porcentagem de tempo que ocupa, na programação das televisões latino- } \\
\text { americanas, cada um dos macrogêneros }\end{array}$} \\
\hline Macrogênero & \% de tempo \\
\hline Ficção & $33 \%$ \\
\hline Informação & $29 \%$ \\
\hline Infantil & $12 \%$ \\
\hline Variedades & $12 \%$ \\
\hline Esportes & $5 \%$ \\
\hline Infoshow & $4 \%$ \\
\hline Culturais & $2 \%$ \\
\hline Televendas & $2 \%$ \\
\hline Outro & $1 \%$ \\
\hline Total & $100 \%$ \\
\hline & \\
\hline & \\
\hline
\end{tabular}


É bem nítido que o gênero ficção predomina, ainda que levemente, sobre a informação. Além disso, o pesquisador nos informa que $90 \%$ deste gênero é composto por telenovelas, estando os filmes em segundo lugar e as séries cômicas logo em seguida. Outra informação importante da pesquisa de Garza é que o gênero ficção, e em particular as telenovelas, é o único que consegue ser exportado e alcançar sucesso entre os diferentes países latino-americanos, com destaque especial para a produção mexicana. Convém ainda mencionar que, se para a telenovela os dados são relevantes, para a radionovela o seu sucesso foi bem marcado como precursor da dramaturgia televisiva, o que revela que seu índice de sucesso não é mais o mesmo, apesar de sua permanência na atualidade (GALAY, 2015).

O que garante o sucesso da exportação dos dois gêneros midiáticos é o que Javier Martínez Garza chama de proximidade cultural: uma vez que as culturas midiáticas latino-americanas são de alguma forma próximas, seus produtos radiofônicos e televisivos, aos serem usufruídos em outros países diferentes dos países produtores, alcançam igual sucesso por não se distanciarem tanto, culturalmente, de seus públicos iniciais locais. No que tange aos produtos midiáticos com características literárias, o mesmo fenômeno parece acontecer, pois de certa maneira as temáticas, as técnicas e os estilos literários se interseccionam entre os países latino-americanos, com peculiar tendência de reforçar as obras literárias canônicas dos próprios países ou que ali repercutiram - as obras universais da literatura.

A fim de explicitar isso melhor, gostaríamos de analisar duas obras relativamente recentes: a telenovela Los Miserables, produção estadunidense gravada no México e difundida inicialmente pelo canal Telemundo, e as radionovelas Nuestra Señora de París e Los Miserables transmutadas por Mario Vargas Llosa e difundidas no Peru pela radioemissora RPP.

\section{TRADUÇÃO INTERSEMIÓTICA}

Inicialmente cabe dizer que essas adaptações são consideradas, no que concerne ao processo que sofreram, transmutações ou traduções intersemióticas ${ }^{4}$ pelo fato de transladarem os signos verbais para o universo dos signos radiofônicos e televisivos. Ademais, para além da transmutação, outro tipo de tradução acontece: a tradução cultural. Não se pode dizer que o mesmo tipo de transmutação intersemiótica que ocorre em uma cultura é idêntico ao mesmo tipo de transmutação que coloca em

4. Para nos referirmos ao processo de passagem ou transformação de uma obra literária em obras de outros sistemas de signos, utilizaremos neste trabalho o termo tradução intersemiótica ou transmutação. Para seus agentes, será usado transmutador ou tradutor intersemiótico. 
jogo duas culturas diferentes. Logo, ao analisarmos e investigarmos uma tradução intersemiótica, é preciso levar em consideração se este processo se dá dentro de uma mesma cultura ou em duas culturas diferentes.

Segundo Peeter Torop (2003), a transmutação pode ser vista como um tipo de tradução extratextual - em que textos feitos em uma substância (por exemplo, a verbal) são transladados para textos de outras substâncias (por exemplo, a audiovisual) - e em que é possível observar uma correlação entre os tipos de informações encontrados em ambos os textos a fim de se referenciar o texto fonte. Torop ainda diz que só é possível o reconhecimento das noções de comunicabilidade, intextextualidade e interdiscursividade entre os dois textos artísticos se se reconhecer a existência da intermedialidade que os une no mundo contemporâneo.

Com fundamentação nesta constatação do processo de convergência de mídias (a intermidialidade) é que se poderá reconhecer o que Peeter Torop (2003, p. 257) nomeia espaço intertextual:

O espaço intertextual é uma realidade dupla para todas as artes. Um texto nasce em um espaço intertextual e pode ter dois tipos de interconexões com este espaço: conexões regulares de tradição; e conexões casuais (mais subjetivas) de criação. Um texto é percebido em outro espaço intertextual, o qual acaba por ser o campo de mais ou menos conexões casuais com outros textos em que o texto adquire novos significados e muitas vezes perde o seu significado inerente (tradução nossa).

Isto é, ao se transmutar de uma arte/mídia para outra arte/mídia, delineiam-se dois espaços culturais do artista: a tradição de sua cultura e seus artefatos culturais pessoais. Provavelmente, devido a estas duas características que impregnam o texto fonte (a arte/mídia fonte), se constrói ou se nomeia as ideias de singularidade da obra e de autoria do artista. Já para o adaptador ou tradutor intersemiótico, possivelmente, será a busca da combinação das duas instâncias do espaço intertextual do artista que qualificará sua obra como tradução/adaptação. Consequentemente a esta busca e, em especial, por sua colocação em outra arte/mídia, será criado pelo transmutador um terceiro espaço, intertextual, que traz como complemento outras interpretações, outros modos de ver a obra - uma vez que será o resultado do artista primeiro (o autor da obra fonte) com o artista segundo (o autor da adaptação).

Parece-nos importante frisar que, junto às reflexões acima, há também de se ponderar a importância do futuro apreciador da obra transmutada. Ao levar em consideração a comunidade de interpretação de determinada obra no processo de transmutação, fica perceptível que muitas das produções artísticas e midiáticas contemporâneas, por mais que tenham a singularidade do seu criador e de sua própria linguagem, são feitas com o princípio de "se há um texto/obra este/a será 
lido/a". Em outras palavras, a recepção futura imaginada para o texto afeta de alguma forma a adaptação, uma espécie de espectador/leitor-modelo (ECO, 2015) se faz presente no processo de transmutação, bem como em sua existência.

De forma concisa, convém afirmar que para a tradução intersemiótica temos como aspectos problemáticos atualmente: as linguagens artísticas e midiáticas (com ênfase no ponto de vista técnico), a natureza intertextual das duas obras em conexão, os níveis de inferências de uma obra a outra, os pontos de ativação de uma obra na outra e a importância do papel de uma obra para a outra.

No que tange especialmente às transmutações ocorridas do texto literário para o rádio e a televisão, convém ainda fazer as seguintes observações sumarizadas no quadro abaixo:

\begin{tabular}{|c|c|c|}
\hline \multicolumn{2}{|c|}{ Quadro 3: Meios de Comunicação Literária } \\
\hline Texto literário & Radionovela & Telenovela \\
\hline Apelo verbal & Apelo auditivo & Apelo visual \\
\hline $\begin{array}{c}\text { Escrito independentemente se vai } \\
\text { ser compreendido ou não }\end{array}$ & Feita para ser compreendida \\
\hline Autoria individual & Autoria coletiva \\
\hline Obra artística & Obra artística-comercial \\
\hline \multicolumn{2}{|c|}{ Há uma provocação de sensações individuais } \\
\hline
\end{tabular}

O texto literário tem um apelo verbal, pois é preciso primeiramente ser um indivíduo letrado ou estar inserido em uma comunidade letrada para ter acesso ao seu conteúdo; em segundo lugar, ele reivindica o conhecimento de mundo e a capacidade de fazer associações que a escrita sugere; e por fim, leva à reflexão, em uma das múltiplas interpretações possíveis, visto que a obra literária é aberta. Já a radionovela, com apelo à audição, e a telenovela, com apelo à visão (apesar de sabermos que também há o áudio), fazem com que o apelo cognitivo muitas vezes seja baixo devido ao fato da compreensão ou uma das interpretações possíveis vir, de certa forma, pronta para seus espectadores. Desse modo, podemos mencionar que há uma espécie de gradação de recepção do texto literário: do menos "pronto", que é o texto literário na mídia verbal, passando por uma mídia mais explícita, o rádio, até chegar à "explicitude total" da televisão. Assim, tem-se que a obra literária permite diversas formas de apreensão, porque é texto escrito e a escrita nunca é transparente em sua totalidade. A radionovela entrega já algo mais ou menos "pronto", embora também permita mais "imaginação" porque opera apenas com o som. A telenovela é mais "explícita" porque não deixa muita margem de interpretação 
ao apreciador - em particular no que tange à descrição física e psicológica -, embora se perceba que na atualidade os novos recursos de criação da linguagem televisiva instigam diferentes interpretações por parte do público. É por causa disso que se pode dizer que muitas vezes a literatura é escrita independentemente de se vai ser compreendida ou não ${ }^{5}$, contrariamente à radionovela e à telenovela, que precisam de alguma forma de compreensões diretas e objetivas a fim de cativar seu receptor e garantir o sucesso da obra. É oportuno dizer que todos esses gêneros midiáticos (literatura, radionovela e telenovela) apresentam modos de apreensão e compreensão singulares, cada um com suas linguagens e suas diferentes relações de público, de comércio e de arte.

Note-se também que, quando se trata de obra literária, estamos de alguma forma nos remetendo à autoria individual, o que já não acontece nos gêneros radionovela e telenovela, em que a obra passa por várias instâncias autorais até serem transformadas em um único produto a ser usufruído. Ou seja, tanto radionovela quanto telenovela passam pela tradução coletiva, que "é o resultado de um movimento dialógico entre discursos em um processo ativo de respondibilidade, implicando: recepção, criação, opções, enformações, estilizações etc." (SILVA JUNIOR, GANDARA, 2015, s/p).

Enfim, não podemos deixar de mencionar que radionovela e telenovela estão imbricadas em relações comerciais. Elas vêm semeadas de propagandas e merchandising que fazem apelo ao consumismo e que elevam a obra ao patamar artístico-comercial, o que não é, em princípio, o caso das obras literárias. Percebe-se que enquanto o texto literário ainda mantém uma provocação de sensações individuais "fora" do capitalismo, radionovela e telenovela surgem de alguma forma ligadas a esse modo de produção econômica.

É perceptível que a transmutação de uma linguagem em outra acarreta várias diferenças, bem como realoca a obra em outros territórios artísticos, dandolhe sobrevida, deixando rastros de seu original e acima de tudo exercendo o que Bakthin (2011) chamou de exotopia, a tentativa de se posicionar no ponto de vista do outro e tentar expô-lo em seguida, o que o agente da tradução intersemiótica sempre tenta fazer.

5. Embora se saiba que o mercado editorial se pauta pelo potencial de venda de seus produtos e que escritores precisem de leitores, devido à lógica de mercado capitalista e ao cunho político e ideológico a que se buscar aderir, há no mercado editorial obras que negam a lógica de mercado, um teor político ou ideológico em voga ou mesmo uma prescrição de público específico, por exemplo: Grande Sertão: Veredas de João Guimarães Rosa, Galáxias de Haroldo de Campos, Finnegans Wake de James Joyce, O Arco-Iris da Gravidade de Thomas Pynchon, A Divina Comédia de Dante, Paradiso de José Lezama Lima, O Jogo da Amarelinha de Julio Cortázar, Os Cantos de Ezra Pound, Cristo versus Arizona de Camilo José Cela, Moby Dick de Herman Melville, O Som e a Fúria do William Falkner, dentre outros. 


\section{DOIS ROMANCES DE VICTOR HUGO LATINO-AMERICANIZADOS}

A telenovela Los Miserables, adaptação do romance de Victor Hugo pela roteirista venezuelana Valentina Párraga, estreou em 2014 na emissora estadunidense Telemundo ${ }^{6}$. A novela foi produzida no México e totalmente gravada em espanhol. Todavia, contrariamente à produção televisiva mexicana de 1973 com título homônimo, a adaptação de Párraga é ambientada na contemporaneidade. Segundo o site da produção, na entrada "acerca de la novela"

'Los Miserables' es una historia de perseguidores y perseguidos, en la que todos los personajes van tejiendo nudos de suspenso, acción y muerte en un mundo que los obligará a sacar las garras para poder defenderse de sus enemigos, aunque la lucha más dura le tocará justamente a Lucía Durán "Lucha". Lucía es una mujer perseguida por la ley pero inocente, que tiene que resistir, luchar y ocultarse tenazmente y con astucia, hasta demostrar su integridad ante su perseguidor, Daniel Ponce, jefe de detectives del departamento de narcóticos y quien es también el hombre al que ella ama. Pese a todas las adversidades, la gran disyuntiva será saber si en realidad el amor, la fe y la justicia se lograrán anteponer y vencer por encima de todo lo demás.

Ao lermos a sinopse da novela e não nos depararmos com os célebres nomes dos personagens Jean Valjean, Javert e Fantine, imaginamos que a novela é apenas inspirada no romance de Hugo. Entretanto, ao buscarmos a substância textual do romance hugoano na telenovela, encontramos personagens, motivos e situações readaptados. Por exemplo: Jean Valjean é Lucía Durán, e Javert é Daniel Ponce; a perseguição, a busca pela justiça se mantêm; a prisão de ambos os personagens principais igualmente está presente, todavia são referentes a crimes contextuais de suas épocas (roubo de pão e cúmplice em delito cotidiano). Tais readaptações dão novos sentidos à trama hugoana e até politizam situações como o papel da mulher ex-prisioneira na sociedade vivido pela protagonista, bem como a questão do narcotráfico, problema social muito agudo no México.

6. A Telemundo foi fundada em Porto Rico em 1954, mas atualmente tem sua sede na Flórida, Estados Unidos. É o segundo maior canal norte-americano de TV a cabo com grande audiência no país com programas feitos majoritariamente em espanhol. Além disso, essa emissora de TV está presente em 23 países latino-americanos, bem como é uma das principais emissoras norte-americanas que produzem telenovelas com o know-how da Rede Globo de TV e que as exportam para outros países consumidores do gênero televisivo. Los Miserables desde sua estreia foi transmitida em diversos países latino-americanos (em 2015: México, Bolívia, Costa Rica, República Dominicana, Panamá; em 2016: Nicarágua, Peru, Porto Rico, Equador, El Salvador, Venezuela; e 2018: Colômbia), por isso, é uma de nossas justificativas de escolher analisar esta telenovela, além de ter a obra de Victor Hugo considerada como clássico pela história literária.

7. Texto disponível em: < http://www.telemundo.com/novelas/los-miserables $>$. Acesso em $11 \mathrm{de}$ fevereiro de 2018. Acesso em 19 de janeiro de 18.o suporte fr 
Como se pode notar, tal tipo de transmutação é proposital. Ela considera o contexto cultural hispano-americano e se acomoda à mídia e às necessidades deste gênero televisivo - que geralmente retrata a contemporaneidade, é veloz e aguça a curiosidade do telespectador em "ser/ter/poder" (ser como a atriz/ator tal, ter o mesmo que tal personagem, poder torcer por algum personagem/situação na trama). A participação do telespectador é tão importante para a telenovela que são as pesquisas de audiência que medem se aquele produto está tendo sucesso ou não; ou o que se adapta da trama de Hugo para que o telespectador possa encontrar referências, mas ao mesmo tempo não se projete para fora de sua cultura ou veja algo não-padronizado da linguagem televisiva. Aqui não queremos afirmar que já não existam mais novelas de época, mas têm cada vez mais existido novelas que adaptam a obra literária para o ambiente atual de seu telespectador, a exemplo da adaptação de Conde de Monte Cristo de Alexandre Dumas por José Ignacio Cabrujas na Venezuela em 1985 com La Dueña, ou Amores roubados, adaptação brasileira de 2014 em forma de minissérie do romance oitocentista A emparedada da Rua Nova, de Carneiro Vilela, dentre tantos outros que poderíamos citar.

O melodrama que também embebe toda a trama do romance de Victor Hugo se faz presente na telenovela Los Miserables de forma extremante parecida no que tange aos personagens bons e maus bem delineados e aos temas da reparação da injustiça e da realização amorosa. Este último chega mesmo a culminar na união final dos dois personagens principais da trama - Lucía e Daniel - que "equivalem" analogicamente a Jean Valjean e a Fantine que, como se sabe, morrem no final do romance hugoano.

Muito mais que uma tradução externa do sistema semiótico da literatura para o sistema semiótico da telenovela, a tradução televisiva para a contemporaneidade é uma tradução interna entre esses dois sistemas semióticos em que as correspondências são feitas com base nos conteúdos das duas obras em cotejo. $\mathrm{O}$ apelo cultural neste tipo de tradução interna é bem marcado, tanto no quesito formal - pois há o respeito ao formato da telenovela latino-americana - quanto no quesito argumentativo ideias, tramas e enredos são retomados de forma atualizada. Por exemplo: os personagens do romance Gravoche e Cosette são retomados na novela como os personagens Roxanita e Memín. Eles ficam aos cuidados de Lucía e são crianças sofredoras da realidade política e social que envolve todos os outros personagens adultos da trama. No romance, Gravoche é um garoto das ruas de Paris que auxilia seu pai a fugir da prisão e também ajuda os revoltosos da Insurreição Republicana de 1832. Já Cosette, filha de Fantine, que aos cuidados da família Thénardier é explorada como empregada doméstica, mesmo sendo uma criança, no desenrolar 
do romance é adotada por Jean Valjean, que se ocupa dela até seu último suspiro. Os dois personagens hugoanos são vítimas do contexto sociopolítico francês do século XIX, assim como as crianças da telenovela no contexto contemporâneo mexicano.

O exercício exotópico da novelista ao transmutar para a contemporaneidade o romance também apresenta uma estrutura profunda do pensamento hugoano sintetizado no prefácio de Les Misérables (HUGO, 2012, p. 27):

\begin{abstract}
Enquanto, por efeito de leis e costumes, houver proscrição social, forçando a existência, em plena civilização, de verdadeiros infernos, e desvirtuando, por humana fatalidade, um destino por natureza divino; enquanto os três problemas do século - a degradação do homem pelo proletariado, a prostituição da mulher pela fome, e a atrofia da criança pela ignorância - não forem resolvidos; enquanto houver lugares onde seja possível a asfixia social; em outras palavras, e de um ponto de vista mais amplo ainda, enquanto sobre a terra houver ignorância e miséria, livros como este não serão inúteis.
\end{abstract}

Apesar das duas obras (literária e televisiva) serem ficção, percebe-se que há o interesse em discutir problemas sociais de suas épocas. Em ambas há o prazer estético e, por vezes, o entretenimento; todavia, o fato da ficção imitar a realidade (e vice-versa) apresenta-se como princípio norteador da tradução intersemiótica interna e culturalmente marcada. Pode-se até inferir que há, em particular na telenovela, a união dos princípios ideológicos hugoanos (além dos estéticos) somados aos da roteirista, a revelar que, mesmo no plano profundo da obra audiovisual, acontece a tradução coletiva.

Quanto às radionovelas Nuestra Señora de París e Los Miserables, estas fizeram parte do projeto idealizado e executado por RPP (Radio Programas del Perú) intitulado Mi novela favorita (2008-2011). Mario Vargas Llosa foi o convidado da emissora para adaptar, comentar e apresentar este programa pelo fato de ser um premiado e prestigiado autor latino-americano e também porque os livros adaptados estavam entre os que mais aprecia. Inicialmente, Mi novela favorita era somente um programa de rádio e produzido para o Peru, mas, devido ao seu sucesso, se tornou também acessível em CD de áudio e CD-ROM, e recentemente está sendo reprisado em outros países como a Colômbia ${ }^{8}$, por exemplo. Em poucas palavras, o empreendimento poderia ser sintetizado na descrição da própria radioemissora disponível em seu site à época9 :

8. Notícia divulgada pelo Ministerio de Tecnologías de la Información y las Comunicaciones (MTIC) da Colômbia no seu portal virtual: <http://www.mintic.gov.co/portal/604/w3-article-14444 html $>$. Acesso em 11 de fevereiro de 2018.

9. Esta afirmativa, segundo nossas pesquisas, aparenta ser a nota de apresentação de Mi novela favorita à época de seu sucesso na RPP. Infelizmente, as notícias sobre o programa não estão mais disponíveis para confirmarmos esta assertiva. Entretanto, pelos vários sites que apresentam esta nota se referindo ao site da rádio RPP (http://rpp.pe), acreditamos que tal nota é verídica. A citação mencionada aqui, dentre os inúmeros sites em que é possível encontrá-la, está disponível em: < http://www.formandotec.com/2010/06/mi-novela-favorita-audionovelas.html > . Acesso em $11 \mathrm{de}$ fevereiro de 2018. 
Mi novela favorita es un programa en donde a lo largo de una hora de duración se trata de resumir a manera de radionovela los principales libros de la literatura universal, contando para tal efecto con la participación de los principales actores peruanos de teatro o televisión quienes ponen la voz a los principales personajes de la obra, contando con la presentación del escritor Mario Vargas Llosa contando aspectos de la obra como de la biografía de sus autores.

De fato, Mi Novela Favorita teve quatro temporadas totalizando 52 radionovelas em que Nuestra Señora de París foi a décima terceira da primeira temporada e Los Miserables a oitava da segunda temporada. Cabe aqui mencionar que as obras escolhidas para esta análise têm, respectivamente, mais de 500 páginas (Notre Dame de Paris) e quase 2.000 (Les Misérables), o que a princípio dificultaria muito sua condensação nos mais ou menos 55 minutos de produção da radionovela, visto que a obra de Hugo, se lida, decerto exigiria várias dezenas de horas. Entretanto, ao considerarmos a substância textual, a linguagem radiofônica e o público a quem está sendo dirigida esta obra "fonoliterária", foi possível, sim, colocar as radionovelas peruanas no patamar de adaptação sem que precisemos recorrer à tradicional dicotomia fidelidade/traição.

O fato da adaptação radiofônica ter uma preocupação compreensivelmente grande com o público revela em parte seu vínculo estreito com o gênero melodrama, junto é claro com a performance vocal dos radioatores e com a reescrita condensada do texto que, juntas, põem em realce as ações do enredo. A linguagem radiofônica é sumarizada em quatro aspectos: palavra, música, efeitos sonoros e silêncio. Tais aspectos são reunidos a fim de formar o produto final: a radionovela. Ou seja, há também nesta obra a tradução coletiva. No caso das duas radionovelas Nuestra Señora de París e Los Miserables, vemos que o texto foi transmutado por Mario Vargas Llosa, as dramatizações feitas por atores de telenovela que emprestaram suas vozes aos personagens e os efeitos sonoros e a música foram trabalhados com o diretor e técnicos de sonoplastia da emissora RPP.

No tocante à transmutação em si, podemos observar quatro procedimentos estratégicos: a performance vocal, a utilização do conhecimento objetivo do mundo sonoro, a criação de atmosferas musicais e a tradução intersemiótica interna ${ }^{10}$. Basicamente são esses procedimentos que retrabalham as descrições presentes no romance: a performance vocal, ao ser identificada pelo tom da voz, sugere características do personagem (voz de mulher adulta para Esmeralda e voz de criança do sexo feminino para Cosette); a criação de ambientações sonoras pela canção ou pela música ambiente insinua as emoções e as ações dos personagens (as fugas de Esmeralda são fortalecidas com uma música de fundo mais intensa e muito

10. Para um maior aprofundamento sobre transmutação para o rádio consultar o texto "Da tradução intersemiótica: Claude Gueux de Victor Hugo no rádio" (REIS, 2013). 
dramática), a utilização do conhecimento objetivo do mundo sonoro proporciona a identificação de objetos e ações não-abstratas ou psicológicas (quando Esmeralda dá água a Quasímodo escuta-se o som da água e dos goles; ou quando se escuta Cosette varrendo a casa onde morava).

Segundo Vargas Llosa ${ }^{11}$, em uma entrevista dada a respeito da série Mi novela favorita, as obras foram escolhidas pelo critério irrefutável do alargamento de suas fronteiras temporais, geográficas, linguísticas e temáticas, na busca de entreter o grande público sem sacrificar a qualidade do caráter e da riqueza literária de cada uma. A finalidade, segundo Vargas Llosa, é agradar aos mais diversos ouvintes tanto aquele que só procura diversão quanto aquele que preza pela estética da obra - e levar os ouvintes a buscar os textos originais. Também visa mostrar a influência e a importância da literatura no mundo contemporâneo em que as pessoas parecem estar apartadas dos livros pelos percalços da vida cotidiana. $\mathrm{O}$ autor ainda afirma que os romances transmutados têm a vitalidade intrínseca de poderem ser traduzidos para outra linguagem e que essa experiência da literatura em outro meio ajuda o ser o humano a ser educado na sensibilidade, na imaginação e nas aptidões cognitivas. De fato, retrabalhar o enredo de um romance tal com Notre-Dame de Paris ou Les Misérables para a radionovela é de alguma forma alargar as fronteiras, do papel para as ondas sonoras, bem como buscar no romance tanto aquilo que faz parte do gênero radiofônico (por exemplo: as características do melodrama) como a essência do pensamento de Hugo que impregna todo o texto.

Estas duas transmutações hugoanas feitas no rádio trazem para o rádio-ouvinte dois aspectos singulares do tempo atual e também da própria mídia: a rapidez e o trabalho com o som. O fato destas duas adaptações levarem em conta o tempo de escuta "disponível" e também a capacidade de ambientação do som para o mundo sonoro do ouvinte as torna também uma tradução cultural. De alguma forma, essas radionovelas despertaram a tradição cultural de telenovelas latino-americanas no Peru e também deixam marcas singulares de seus agentes de produção: Vargas Llosa, os radioatores, diretores, dentre outros.

\section{CONCLUSÃO}

Unindo as reflexões aqui explanadas, podemos deduzir que o conceito de tradução intersemiótica tal como apresentado por Roman Jakobson (2007) parece

11. Entrevista disponível em: < https://www.youtube.com/watch?v=OcKnjNpzxsU>. Acesso em 11 de fevereiro de 2018. 
estar ganhando outros rumos e que suas fronteiras estão cada vez mais tênues. Isto se dá porque o processo de transmutação não está mais voltado apenas para as correspondências mais rasas e facilmente perceptíveis entre a obra fonte e a obra alvo. Com efeito, a tradução intersemiótica tem se mostrado também um processo de interpretação de estruturas mais profundas e culturalmente marcadas em âmbitos nacionais, quiçá locais.

Em conjunto com estas constatações, reconhece-se cada vez mais que as adaptações literárias atuais têm o intuito de aproximar públicos e obras que pareciam tempos atrás impossíveis de se encontrarem, se apaixonarem e se casarem. Certamente, pode haver exceções em relação às conclusões que enunciamos neste trabalho, mas o que se nota é que cada vez mais as artes-relés estão dialogando com a literatura e aproximando o literário (canônico ou popular) por plataformas de comunicação (poéticas ou não) de públicos ditos não-literários.

No que tange às adaptações (o produto) e traduções intersemiótica (o processo), não poderíamos talvez dizer que para os latino-americanos seriam a radionovela e a telenovela nossas artes-relés literárias? Sem excluir nenhum estrato social latino-americano, "sim!" seria a resposta mais conveniente para esta questão.

\section{REFERÊNCIAS BIBLIOGRÁFICAS}

BAKHTIN, M. (2011). Estética da criação verbal. Tradução de Paulo Bezerra. 6 ed. São Paulo: Martins Fontes.

BALOGH, A. M. (2002). O discurso ficcional na televisão. São Paulo: EDUSP.

CANCLINI, N.G. (2007). A globalização imaginada. Tradução de Sérgio Molina. São Paulo: Iluminuras.

CESÁRIO, D. V. et alii (2006). Radionovela: a magia do passado encantando o presente. Fortaleza: LCT.

DUFIEF, A-S (2001). Le théâtre au XIXe siècle: du romantisme au symbolisme. Paris: Bréal.

ECO, U. (2015). Os limites da interpretação. Tradução de Pérola de Carvalho. São Paulo: Perspectiva.

EVEN-ZOHAR, I. (2013). "O Sistema Literário". Tradução de Luis Fernando Marozo e Yanna Karlla Cunha. In: Revista Translatio. №5. pp. 21-45. Disponível em: $<$ http:// 
www.seer.ufrgs.br/index.php/translatio/article/view/42900/27135 >. Acesso em 11 de fevereiro de 2018.

GALAY, F. G. (2015). "Revisitando el radiodrama en la actualidad". In: Comunicación y Medios. no 31 . Instituto de la Comunicación e Imagen, ICEI. Universidad de Chile. p. 133-149. Disponível em: < https://comunicacionymedios.uchile.cl/index.php/ RCM/article/view/35769 > . Acesso em 4 de março de 2018.

GARZA, J. M. (2005). "La oferta de televisión en América Latina: hacia un análisis de flujos". In: ZER -Revista de estudios de Comunicación. V. 10, nº 19, pp. 145-127. Disponível em: < http://www.ehu.eus/ojs/index.php/Zer/article/view/3848 >. Acesso em 11 de fevereiro de 2018.

HUGO, V. (1997). "Préface". In: Ruy Blas. Paris: Gallimard.

HUGO, V. (2012). Os miseráveis. Tradução de Frederico Ozanam Pessoa de Barros. São Paulo: Cosac Naify.

HUPPES, I. (2000). Melodrama: o gênero e sua permanência. São Paulo: Ateliê Editorial.

JAKOBSON, Roman (2007). Linguística e comunicação. Tradução de Izidoro Blikstein e José Paulo Paes. 24a ed. São Paulo: Cultrix.

LÓPEZ, T. B. (2012). "La radio en América latina y el Caribe: mapa interactivo". In: Chasqui - Revista latinoamericana de comunicación. Núm. 118, pp. 37-41. Disponível em: <http:// www.revistachasqui.org/index.php/chasqui/article/view/145>. Acesso em 11 de fevereiro de 2018.

MEYER, M. (1996) Folhetim: uma história. São Paulo: Companhia das Letras.

RADIO LIBRES, 2017. La radio en América latina y el Caribe: Mapa Interactivo 2017. Disponível em: $<$ https://radioslibres.net/article/mapa-de-radios-de-america-latina-y-caribe-2017/ $>$. Acesso em 4 de março de 2018.

REIS, D. S. (2013). "Da tradução intersemiótica: Claude Gueux de Victor Hugo no rádio". In: Revista Ecos, V. 15, Ano X, no 02, pp. 33-53. Disponível em: < https://periodicos. unemat.br/index.php/ecos/article/view/628>. Acesso em 11 de fevereiro de 2018.

RONCAGLIOLO, R. (1996). "La integración audiovisual en América Latina: estados, empresas y productores independientes". In: CANCLINI, N.G. (org.) Culturas en globalización, América Latina-Europa-Estados Unidos: libre comercio e integración. Caracas: Seminario de Estudios de la Cultura (CNCA)/CLACSO/Nueva Sociedad. 
SCHAEFFER, P. (2010). Ensaio sobre o rádio e o cinema: estética e técnica das artes-relé, 1914-1942. Texto estabelecido por Sophie Brunet e Carlos Palombini, com a colaboração de Jacqueline Schaeffer. Prefácio, apresentação, aparato crítico e tradução Carlos Palombini. Belo Horizonte: UFMG.

SILVAJUNIOR, A. R.; GANDARA, L. C. (2015). "A tradução coletiva de Abril despedaçado no âmbito do cinema literário brasileiro Pós-Retomada". In: O Guari - revista eletrônica de literatura. Disponível em: < http://oguari.blogspot.com.br/p/atraducao-coletivade-abril-despedacado.html $>$. Acesso em 11 de fevereiro de 2018.

SILVA, F. L. P. (2005). "Melodrama, folhetim e telenovela: anotações para um estudo comparativo". In: FACOM, v. 15, 2 sem, pp. 46-54. Disponível em: < http://www. faap.br/revista_faap/revista_facom/facom_15/_flavio_porto.pdf $>$. Acesso em $11 \mathrm{de}$ fevereiro de 2018.

TOROP, P. (2003). "Intersemiosis and Intersemiotic Translation". In: PETRILLI, Susan. Translation Translation. Amsterdam/New York: Rodopi.

TORRES, B. A. (2009). "O movimento de democratização do rádio no panorama latinoamericano". In: Anais do VII Encontro Nacional de História da Mídia. Rede Alcar: Fortaleza. pp. 1-16. Disponível em: <http://www.ufrgs.br/alcar/encontros-nacionais-1/ encontros-nacionais/7o-encontro-20091/>. Acesso em 11 de fevereiro de 2018.

VALÉRY, P. (1936). "Le bilan de l'intelligence". In: Variété III. Paris: Gallimard.

VARGAS LLOSA, Mario (1983). Tia Júlia e o Escrevinbador. Tradução de Remy Gorga. São Paulo: Nova Fronteira.

YAMASHITA, K. T. (2003). Matacão, uma lenda tropical. Tradução de Cristina Maria Teixeira Stevens e Carolina Berard. São Paulo: Zipango.

Recebido: 11/02/2018

Aceito: 05/03/2018 